\title{
DOI: 10.7596/taksad.v6i3.941
}

Citation: Özcan, B., \& Kiraz, A. (2017). Life Satisfaction of Adolescents Living in Northern Cyprus. Journal of History Culture and Art Research, 6(3), 88-106. doi:http://dx.doi.org/10.7596/taksad.v6i3.941

\section{Life Satisfaction of Adolescents Living in Northern Cyprus Kıbrıs'ın Kuzeyinde Yaşayan Ergenlerin Yaşam Memnuniyetleri}

\author{
Aşkın Kiraz ${ }^{1}$, Banu Özcan²
}

\begin{abstract}
In this research, the life satisfaction of adolescents who live in Northern Cyprus is examined. Demographic variables of adolescents have been taken into consideration while life satisfaction has been determined. The study has been completed in a way of scan pattern in accordance with quantitative method. The reachable universe of this study included the students attending 9, 10, 11, and $12^{\text {th }}$ grade in the province of Kyrenia Northern Cyprus. The samples of research group included 436 students composed of 209 boys $(\% 47,8)$ and 227 girls $(\% 52,2)$. The data collection tools used during the research were, Personal Information Form which consists of demographic data and Multidimensional Life Satisfaction Scale. Multidimensional Life Satisfaction Scale consists of friend satisfaction, school satisfaction, environment satisfaction and self satisfaction sub-dimensions. The data has been analyzed with SPSS 20 package program. As a conclusion, within the sub-dimensions of the scale, friend satisfaction sub-dimension level of participants was found to be higher when compared to school, environment and self-satisfaction sub-dimension levels. Additionally, the life satisfaction points of 436 adolescents have shown a meaningful differentiation according to the school type, attended grades and education levels of mother and father. However, there has been no meaningfull differentiation regarding gender, age, number of siblings, the rank of birth, and the working status of mother and father.
\end{abstract}

Keywords: Life satisfaction, Adolescents, Adolescence, New generation, Northern Cyprus.

\footnotetext{
${ }^{1}$ Doç. Dr., Yakın Doğu Üniversitesi, Atatürk Eğitim Fakültesi, Lefkoşa, KKTC. E-mail: askin.kiraz@neu.edu.tr

${ }^{2}$ Uzm., Yakın Doğu Üniversitesi, Atatürk Eğitim Fakültesi, Lefkoşa, KKTC. E-mail: banusupceler@gmail.com
} 


\section{Öz}

$\mathrm{Bu}$ araştırmada, Kuzey Kıbrıs’ta yaşayan ergenlerin yaşam memnuniyetleri incelenmiştir. Çalışmada ergenlerin yaşam memnuniyetleri belirlenirken bazı demografik değişkenler göz önüne alınmıştır. Çalışma nicel araştırma yöntemine uygun olarak, tarama deseniyle yürütülmüştür. Araştırmanın ulaşılabilir evrenini Kuzey Kıbrıs'ın Girne Kazasında, 20142015 eğitim öğretim yılında 9, 10, 11 ve 12. sınıfa devam eden öğrenciler oluşturmaktadır. Araştırmanın örneklem grubu, evren içerisinde yer alan beş lisenin 9, 10, 11, 12. sınıflarına devam eden 209'u erkek (\%47,9), 227'si k1z (\%52,1) olmak üzere toplamda 436 öğrenciden oluşmuştur. Araştırmada veri toplama aracı olarak demografik bilgilerin yer aldığı Kişisel Bilgi Formu ve Çok Boyutlu Öğrenci Yaşam Doyumu Ölçeği kullanılmıştır. Çok Boyutlu Öğrenci Yaşam Doyumu Ölçeği arkadaş doyumu, okul doyumu, çevre doyumu ve benlik doyumu alt boyutlarından oluşmaktadır. Verilerin analizi SPSS 20 paket programı kullanılarak yapılmıştır. Araştırmanın sonucunda 15-19 yaş grubundaki 436 ergenin yaşam doyumlarının en düşük benlik alt boyutunda, en yüksek ise arkadaş alt boyutunda olduğu bulunmuştur. Ayrıca çalışmada okul alt boyutundan alınan yaşam doyumu puanlarının, çevre alt boyutundan alınan yaşam doyumu puanlarından daha yüksek olduğu bulunmuştur. Katılımcıların yaşam doyumu puanlarının okul, sınıf, anne eğitim ve baba eğitim durumuna göre anlamlı bir farklılık gösterdiği bulunmuştur. Fakat cinsiyet, yaş, kardeş sayısı, doğum sırası, anne çalışma ve baba çalışma durumuna göre anlamlı bir farklılık bulunmamıştır.

Anahtar Sözcükler: Yaşam memnuniyeti, Yaşam doyumu, Ergen, Ergenlik, Kuzey Kıbrıs.

\section{Introduction}

Individuals constantly grow since the moment they are born. In this process, in terms of development they go through special periods such as "adolescence". The period which starts with adolescence is called "critical period" (Kulaksızoğlu, 2009) when physical growth and psychological development occur very fast. The adolescent is neither an adult in this period, nor is he/she a child, but in a transition process from childhood to adulthood (Bülbül, 2004). In this process, some psychological and social changes are also observed as a result of the physical change. Physical changes are followed by psychological changes (Tezel, Dzkanz, \& Parlak, 2012). Physical change is seen automatically in time, but psychological change is entirely dependent on the active efforts of the adolescent. In this process, the adolescent feels that he/she belongs neither to the world of children nor to the world of adults. He/she is in a transition area in the middle of the two (Küey, 2008). Nevertheless, he/she is defenseless and fragile and unable to give a meaning to the changes and developments he/she is going 
through. If he/she encounters negative effects in this period, his/her entire life will be affected by this negativity and it will be attached to him/her for his/her entire life (Parman, 2008).

It is essential that the adolescent who is exposed to several changes feels satisfaction from this special period of his life during when he/she is sensitive towards the happenings in the environment. An unsatisfied adolescent can have the wrong environment and encounter negative results. Depending on the level of life satisfaction of the adolescent and his/her family and social environment, these negativities can lead to depression. If the individual suffers from depression, he/she can experience changes in his/her body. These changes can cause the adolescent to experience loneliness, lack of trust towards others, aggression, anorexia and sleeping disorders (Demirel \& Canat, 2004).

Life satisfaction can be defined as the difference between what a person wants in his/her life and what he/she achieves (Selçukoğlu, 2001) or the situation emerging as a result of the expectations and achievements of a person (Özer and Karabulut, 2003). It has been observed that life satisfaction is also directly proportional to the level of happiness (Collard, 2006). The self-confidence of individuals who obtain satisfaction from their lives is also high and they establish healthy relations with the people around them (Diener, Diener, \& Tamir, 2004).

There are several factors which affect the life satisfaction of an adolescent. These factors can be listed as the education that adolescent receive from his/her family, the education offered at the school, the environment in which he/she lives and grows, and cultural characteristics of the region he/she is living and growing (Baştemur, 2006). Satisfaction of adolescents from their lives affects their entire life in terms of emotional and social development and having a positive viewpoint can turn their life into positive (Çivitci, 2009). There are situations which affect life satisfaction of adolescents and their positive point of view. These situations are perceived social attention, determining positive targets in individual lives, or making activities and sports (Doğan, 2006). As the life satisfaction obtained affects their entire life, it has a specifically important place.

The purpose of the study is to determine the life-satisfaction levels of students at the second stage of secondary school living in Northern Cyprus who were selected as adolescent group. The sub-purposes answered while exploring the purpose of the study are as follows:

1. How are the life-satisfaction levels of adolescents distributed depending on friends, school, environment and self sub-dimensions of the scale?

2. Do the life-satisfaction levels of adolescents vary according to demographic data? 
Adolescence period is one of the most important periods of human development. Adolescence period affects the future characters of individuals depending on the nature of the period and their behaviours in the society (Çiftci, 2015). For this reason, this period is important in the identity-development of the adolescent and directing his/her future. If the adolescent learns to live in peace and as satisfaction with life, his/her entire life will be affected positively.

\section{Method}

\section{Model of Research}

In the study, quantitative research methods were used in examining the lifesatisfaction of adolescents at the secondary schools in Kyrenia district of Northern Cyprus. The results were put forward with numerical data. Scan pattern was used in the research in this context. In scan pattern, prominent features of a group are explored (Karasar, 2012). In this research, depending on the definition of pattern, life satisfaction of adolescents was determined according to friend, school, environment, and self-satisfaction sub-dimensions.

\section{Participants}

The universe consists of secondary school students who are enrolled at state high schools and private high schools in Kyrenia district. There are six schools in the universe. School principals of the six schools were reached, and except one, five of them stated that they would volunteer to support the study. In this context, 436 students in the universe formed the sample group of the study. Demographic information of the sample group who participated in the study is given below.

Table 1. Sample Distribution

\begin{tabular}{llll}
\hline & & \multicolumn{1}{c}{$f$} & $\%$ \\
\hline \multirow{3}{*}{ Gender } & Male & 209 & 47.9 \\
\hline & Female & & \\
& & & \\
& 15 & 150 & 52.1 \\
& 16 & 128 & 34.4 \\
& & & 29.4
\end{tabular}




\begin{tabular}{|c|c|c|c|c|}
\hline \multirow[t]{3}{*}{ Age } & 17 & 106 & \multicolumn{2}{|l|}{24.3} \\
\hline & 18 & 49 & \multicolumn{2}{|l|}{11.2} \\
\hline & 19 & 3 & \multicolumn{2}{|l|}{0.7} \\
\hline \multirow{5}{*}{ School Type } & Highschool 1 & 135 & \multicolumn{2}{|c|}{31.0} \\
\hline & Highschool 2 & 122 & \multicolumn{2}{|c|}{28.0} \\
\hline & Highschool 3 & 29 & \multicolumn{2}{|l|}{6.6} \\
\hline & Highschool 4 & ; & \multicolumn{2}{|l|}{1.2} \\
\hline & Highschool 5 & $\lfloor 45$ & \multicolumn{2}{|c|}{33.3} \\
\hline \multirow{4}{*}{ Grade } & 9 & 110 & \multicolumn{2}{|l|}{25.2} \\
\hline & 10 & 144 & \multicolumn{2}{|l|}{33.0} \\
\hline & 11 & 126 & \multicolumn{2}{|l|}{28.9} \\
\hline & 12 & 56 & \multicolumn{2}{|l|}{12.8} \\
\hline \multirow{6}{*}{ Number of Siblings } & 0 & 56 & \multicolumn{2}{|r|}{12.8} \\
\hline & 1 & 218 & \multicolumn{2}{|r|}{50.0} \\
\hline & 2 & 102 & \multicolumn{2}{|r|}{23.4} \\
\hline & 3 & 42 & \multicolumn{2}{|r|}{9.6} \\
\hline & 4 & 18 & \multicolumn{2}{|r|}{4.1} \\
\hline & First & 232 & & 53.2 \\
\hline \multirow{4}{*}{ Birth Rank } & Second & 66 & & 15.1 \\
\hline & Last & 132 & & 30.3 \\
\hline & Other & 6 & & 1.4 \\
\hline & Illiterate & 18 & \multicolumn{2}{|l|}{4.2} \\
\hline Mother's Educational & Primary School & 138 & \multicolumn{2}{|l|}{31.7} \\
\hline Level & High School & 180 & \multicolumn{2}{|l|}{41.3} \\
\hline
\end{tabular}




\begin{tabular}{|c|c|c|c|c|}
\hline & Bachelor's Degree & 100 & & 22.9 \\
\hline & Illiterate & 8 & & 1.9 \\
\hline Father's Educational & Primary School & 110 & & 25.2 \\
\hline \multirow[t]{2}{*}{ Level } & High School & 212 & & 48.6 \\
\hline & Bachelor's Degree & 106 & & 24.3 \\
\hline Mother's Working & Working & 244 & & 56.0 \\
\hline Status & Non-Working & 192 & & 44.0 \\
\hline Father's Working & Working & 414 & & 95.0 \\
\hline Status & Non-Working & 22 & & 5.0 \\
\hline Total & & 436 & 100.0 & \\
\hline
\end{tabular}

\section{Data Collection Instrument}

In the study, Personal Information Form and Multi-Dimensional Student Life Satisfaction Scale were used as data collection tools. In the Personal Information Form developed by the researcher, gender, age, school, grade, number of siblings, birth rank, education status of parents and employment status of parents of adolescents were asked. Multi-Dimensional Student Life Satisfaction Scale was developed in 1994 by Huebner and adopted to Turkish Language and culture in 2007 by Çivitci. The scale is a 4-likert type scale consisting of 36 items. The scores obtained from the scale which consists of friend, school, environment and self sub-dimensions give a general life satisfactions score. High scores on the scale indicate that life satisfaction is increasing. For this study, the reliability coefficient of the scale was calculated and Cronbach Alpha value was found as .87.

\section{Analysis of Data}

In the research data from 436 students of five high schools in Kyrenia district were collected. Answers given to the personal information form and scale were used as the basic data source. Quantitative data obtained from the scale were evaluated in computer environment and SPSS 20 package program was used for statistical analysis. The research used parametric t-test and ANOVA test in order to explore whether there was a significant 
difference between two sample groups or not. In cases where significant difference was found according to ANOVA test results, TUKEY test was employed in order to identify the groups between which this difference occurred. In analysis, difference significance level was taken as .05 (Büyüköztürk, Bökeoğlu, \& Köklü, 2015). In addition, frequency analysis, which is a descriptive statistical method, was used in order to be able to see the details of some independent variables and demographic structure of the participants.

\section{Findings and Discussion}

\section{Distribution of Life Satisfaction Levels of Adolescents According to the Sub-Dimensions}

The first sub-purpose of the study is "How are the life-satisfaction levels of adolescents distributed depending on friends, school, environment and self sub-dimensions of the scale?". Distribution of life satisfaction levels analyzed for this sub-purpose according to friend, school, environment and self sub-dimensions is given in table 2.

Table 2. Distribution of Life Satisfaction Levels According to the Sub-Dimensions

\begin{tabular}{llllll}
\hline Life & $\mathrm{N}$ & $\overline{\mathrm{X}}$ & SS & Minimum & Maximum
\end{tabular}

Satisfaction

Sub-Dimensions

\begin{tabular}{lccccc}
\hline Friend & 436 & 27.4771 & 3.74189 & 1.00 & 32.00 \\
School & 436 & 21.5986 & 5.11539 & 16.00 & 32.00 \\
Environment & 436 & 20.6009 & 4.72035 & 8.00 & 32.00 \\
Self & 436 & 19.2385 & 3.15398 & 8.00 & 28.00 \\
Total & 436 & & & 11.00 & 24.00 \\
\hline
\end{tabular}

As shown in table 2, average life satisfaction was calculated as 27,4771 in friend subdimension, 21,5986 in school sub-dimension, 20,6009 in environment sub-dimension, and 19,2385 in self sub-dimension. According to these calculations, the lowest average belongs to self sub-dimension and the highest average belongs to friend sub-dimensions. According to 
life satisfaction scale of participants, it can be said that satisfaction in friends sub-dimension is the highest when compared to other dimensions.

Friend sub-dimension of life satisfaction scale consists of eight items in total. When the average score of this dimension is divided into the number of items, knowledge can be obtained as to the extent of satisfaction in terms of friends. In the light of this information, it is clear that friend satisfaction is at a high level $(\overline{\mathrm{X}}=3,43)$. There are six items in the "self" sub-dimension. It is evident that self satisfaction of participants is at a medium level ( $\bar{X}$ $=3,20)$. According to this result, it can be said that life satisfaction of adolescents in terms of friend is higher compared to school, environment and self satisfaction. Similar conclusions can be reached when the literature is reviewed. Some results such as "the life satisfaction of adolescents according to friend sub-dimension is higher than school, environment and self sub-dimensions" are cited by the researchers (Cenkseven, 2004; Flashman, 2012; Hilooğlu \& Cenkseven, 2010). Findings of conducted researches support this conclusion. In addition to this situation, Gong and Fan stated in their research in 2006 that environmental conditions affected life satisfaction of adolescents in a positive direction. It is believed that this difference is caused by the region of study.

\section{Distribution of Life Satisfaction Scores of Adolescents According to the Demographic Information}

Second sub-purpose of the research is "Does the life satisfaction scores of adolescents vary according to demographic information?". In line with this sub-purpose data have been analysed according to the gender, age, school type, grade, number of siblings, rank of birth, education status of parents and working status of parents.

Table 3. Distribution of Life Satisfaction Levels According to the Gender

\begin{tabular}{|c|c|c|c|c|c|c|c|}
\hline & $\mathbf{N}$ & $\bar{X}$ & SS & $\mathbf{t}$ & df & $\mathbf{p}$ & \\
\hline \multirow[t]{2}{*}{ Male } & 209 & 88.30 & 11.16 & & & & $\mathrm{p}>.05$ \\
\hline & & & & 1.924 & 434 & .293 & no significant \\
\hline Female & 227 & 89.47 & 12.04 & & & & difference \\
\hline
\end{tabular}


As can be seen in table 3 , the life satisfaction of male students is 88,30 whereas average score of life satisfaction of female students is calculated as 89,47 . According to analysis results, there is no statistically significant difference between life satisfaction scale scores and genders of participants $(\mathrm{p}=, 293 ; \mathrm{p}>, 05)$. This result shows that life satisfaction level of adolescents does not change according to gender. In the literature it is possible to find studies supporting this result or reporting the opposite result with this study. For example, Mahon, Yarcheski and Yarcheski found in their study in 2005 on university students that gender does not affect well-being. However, in a similar study Cenkseven and Akbaş (2007) found that female university students have a higher life satisfaction than male students.

Table 4. Distribution of Life Satisfaction Levels According to the Age

\begin{tabular}{lllllll}
\hline & $\begin{array}{l}\text { Sum of } \\
\text { Squares }\end{array}$ & df & Mean & $\mathbf{f}$ & $\mathbf{p}$ & \\
\hline Between Groups & 650.091 & 4 & 162.523 & 1.203 & .309 & $\mathrm{p}>.05$ \\
Within Group & 58243.769 & 431 & 135.136 & & $\begin{array}{l}\text { no significant } \\
\text { difference }\end{array}$ \\
Total & 58893.860 & 435 & & & \\
\hline
\end{tabular}

As can be seen in table 4 , f value and $\mathrm{p}$ value, as regards whether life satisfaction scale scores of adolescents change according to age, were calculated as 1,203 and 0,309, respectively. No statistically significant difference has been found between life satisfaction scale scores and ages of participants $(p=, 309 ; p>, 05)$. This finding which occurred according to the data obtained as a result of analysis revealed that life satisfaction levels of adolescents did not change according to age.

Table 5. Distribution of Life Satisfaction Levels According to the School Type

\begin{tabular}{llllllll}
\hline & $\begin{array}{l}\text { Sum of } \\
\text { Squares }\end{array}$ & df & Mean & $\mathbf{f}$ & $\mathbf{p}$ & \\
& & & Square & & & \\
\hline Between Groups & 1224.228 & 3 & 408.076 & 3.057 & .028 & $\mathrm{p}<.05$
\end{tabular}




\begin{tabular}{|c|c|c|c|}
\hline Within Group & 57669.632 & 133.495 & $\begin{array}{l}\text { significant } \\
\text { difference }\end{array}$ \\
\hline Total & 8893.860 & 435 & $1-2$ \\
\hline
\end{tabular}

1: State $(\bar{X}=86,58), 2$ : Private $(\bar{X}=90,76)$

As can be seen in table 5, f value and $\mathrm{p}$ value as regards whether life satisfaction scale scores of adolescents change according to their school type were calculated as 3,057 and 0,028 , respectively. It is seen that there is statistically significant difference between scores of life satisfaction scale and school types of participants $(\mathrm{p}=, 028 ; \mathrm{p}<, 05)$. As a result of TUKEY test which was performed in order to find the groups between which this difference occurred, it is seen that state schools $(\bar{X}=86,58)$ have lower life satisfaction when compared to private schools ( $\bar{X}=90,76)$. According to this finding, it was concluded that adolescents at private high schools have higher life satisfaction compared to adolescents at state high schools. It is believed that the low level of life satisfaction of adolescents at state school is caused by socioeconomic status and interest. Students at private high school have more facilities when compared to students at state school. In addition, it is clear that students and parents at private school receive more interest and care. Such situations are factors that increase life satisfaction. Şener explained that life satisfaction was the "situation which occurs when an individual compares the things that he/she desires and the things that he/she actually has" in his study conducted in 2008. The fact that an adolescent with better socio-economic status has higher life satisfaction can be related to the foregoing. It also reveals the idea that a student who studied in a private high school can also study in his preferred department for his preferred job in a private university. A survey conducted on this subject indicated that people who have intentionally made a preference about their profession experience a lower burnout in their professions (Kiraz \& Özyurtlu, 2014). A similar study in this topic was conducted by Aydoğan in 2010. Aydoğan displayed in his study that the self-respect level of students will increase when monthly income of the family increased. Studies in a similar vein support the finding of the research.

Table 6. Distribution of Life Satisfaction Levels According to the Grade

\begin{tabular}{cccccc} 
Sum of & df & Mean & f & P & \\
Squares & & Square & & & \\
\hline Between Groups 1176.749 & 3 & 392.250 & 2.936 & .033 & $\mathrm{p}<.05$ \\
\hline
\end{tabular}




\begin{tabular}{lcccc}
\hline Within Group & 57717.111 & 432 & 133.604 & $\begin{array}{l}\text { significant } \\
\text { difference }\end{array}$ \\
Total & 58893.860 & 435 & $1-4$ \\
\hline
\end{tabular}

1: $1^{\text {st }} \operatorname{grade}(\overline{\mathrm{X}}=88,00) ; 4: 4^{\text {th }}$ grade $(\overline{\mathrm{X}}=85,32)$

As can be seen in table 6 , $\mathrm{f}$ value and $\mathrm{p}$ value as regards whether life satisfaction scale scores of adolescents change according to their grade were calculated as 2,936 and 0,033, respectively. It is seen that there is statistically significant difference between scores of life satisfaction scale and schools of participants $(\mathrm{p}=, 033 ; \mathrm{p}<, 05)$. As a result of TUKEY test which was performed in order to find the groups between which this difference occurred, it is seen that $1^{\text {st }}$ grade students $(\bar{X}=88,00)$ have lower life satisfaction when compared to $4^{\text {th }}$ grade students ( $\overline{\mathrm{X}}=85,32$ ). It is highly possible that high school $1^{\text {st }}$ grade students have higher life satisfaction compared to high school last grade students, who are preparing to university entrance examinations. The stress they are living during this preparation process leads to a decrease in life satisfaction. One of the most important reasons of examination stress is the pressure exerted of parents and schools on adolescents. Fears and anxieties of an adolescent who is under pressure increases simultaneously. This situation takes the entire social life of the adolescent prisoner. The adolescent fails to attend at social activities (cinema, theater, sports). Therefore, the satisfaction received by adolescent from life decreases. Literature review indicates similar results. Results such as "as grade of adolescents increase, life satisfaction decreases proportionally" were stated by researchers (Başer, 2009; Çivitci, 2009; Kaya \& Saçkes, 2004; Lubin \& Whitlock, 2004).

Table 7. Distribution of Life Satisfaction Levels According to the Sibling Number

\begin{tabular}{lllllll} 
& Sum of & df & Mean & F & P & \\
& Squares & & Square & & \\
\hline Between Groups & 658.410 & 4 & 164.63 & 1.218 & .302 & $\mathrm{p}>.05$ \\
Within Group & 58235.450 & 431 & 135.117 & & no significant \\
& & & & & difference \\
Total & 58893.860 & 435 & & & \\
\hline
\end{tabular}

As can be seen in table 7, f value and $\mathrm{p}$ value as regards whether life satisfaction scale scores of adolescents change according to their sibling number were calculated as 1,218 and 
0,302, respectively. No statistically significant difference between scores of life satisfaction scale and sibling number of participants existed $(\mathrm{p}=, 302 ; \mathrm{p}>, 05)$. This finding which occurred according to the data obtained at the end of analysis, it is clear that life satisfaction of adolescents does not change according to the number of siblings.

Table 8. Distribution of Life Satisfaction Levels According to the Birth Rank

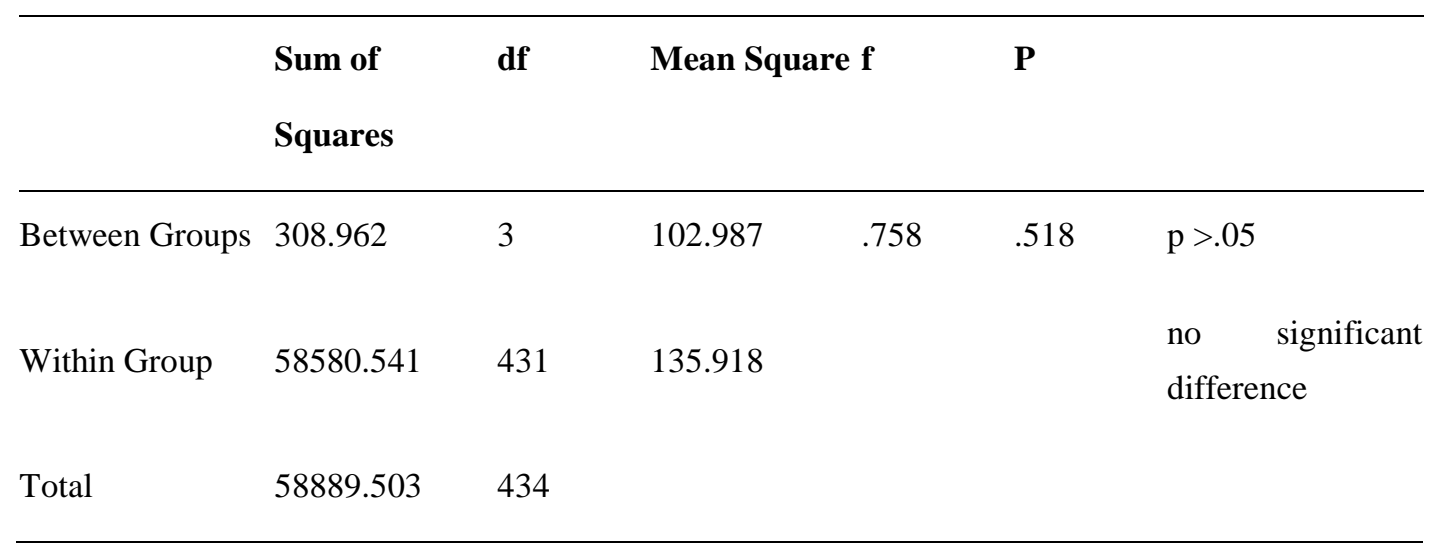

As can be seen in table 8 , f value and $p$ value as regards whether life satisfaction scale scores of adolescents change according to their birth rank were calculated as 0,758 and 0,518, respectively. No statistically significant difference between scores of life satisfaction scale and the birth rank of participants existed $(\mathrm{p}=, 518 ; \mathrm{p}>, 05)$. This finding which occurred as a result of analysis displayed that life expectation level does not change according to birth rank.

Table 9. Distribution of Life Satisfaction Levels According to the Mother's Education Status

\begin{tabular}{|c|c|c|c|c|c|c|}
\hline & $\begin{array}{l}\text { Sum of } \\
\text { Squares }\end{array}$ & df & $\begin{array}{l}\text { Mean } \\
\text { Square }\end{array}$ & $\mathbf{f}$ & $\mathbf{p}$ & \\
\hline Between Groups & 1314.685 & 3 & 438.228 & 3.288 & .021 & $\mathrm{p}<.05$ \\
\hline Within Group & 57579.175 & 432 & 133.285 & & & $\begin{array}{l}\text { significant } \\
\text { difference }\end{array}$ \\
\hline Total & 58893.860 & 435 & & & & $1-4$ \\
\hline
\end{tabular}

1: Illiterate $(\bar{X}=94,44) ; 4$ : Bachelor's Degree $(\bar{X}=87,13)$

As can be seen in table 9, $\mathrm{f}$ value and $\mathrm{p}$ value as regards whether life satisfaction scale scores of adolescents change according to the education status of mother were calculated as 3,288 and 0,021 , respectively. There is statistically significant difference between scores of 
life satisfaction scale and education status of parents of participants existed $(\mathrm{p}=0,21 ; \mathrm{p}<.05)$. As a result of the TUKEY test which was performed in order to find between which groups this difference existed, it is seen that life satisfaction of 1: Illiterate people $(\bar{X}=94,44)$ is higher compared to 4: Bachelor's Degree holders $(\bar{X}=87,13)$. Life satisfaction level of adolescents whose mothers are illiterate turned out to be higher when compared to that of adolescents with university graduate mothers. This finding which emerged according to the data obtained as a result of the analyses revealed that life expectation levels change according to the education status of mother. One of the reasons of the foregoing may be that the illiterate mother has not opportunity for developing herself and spent most of her life with her children. For this reason, a mother who will be closely interested in her children will make contribution to the increase of life satisfaction of her children. In addition, thinking that an illiterate mother will have less expectation from her children, it can be predicted that even small achievements obtained by the child are received by huge satisfaction by the mother and failures do not cause stress and sadness. It can be considered that positive feedbacks received by a child who faces such a situation will lead to an increase in his/her life satisfaction level. It is seen that there are studies which display contradicting results in the literature. For example, in their study conducted in 2014, Gülcan and Bal concluded that education status of mother did not create a significant difference in life satisfaction. Kirt1l (2009), in his study conducted on secondary school students, found that life satisfaction did not show any change on education status of the mother. It is believed that this difference in the literature is caused by the research group or geographical culture.

Table 10. Distribution of Life Satisfaction Levels According to the Father's Education Status

\begin{tabular}{|c|c|c|c|c|c|c|}
\hline & $\begin{array}{l}\text { Sum of } \\
\text { Squares }\end{array}$ & df & $\begin{array}{l}\text { Mean } \\
\text { Square }\end{array}$ & $\mathbf{F}$ & $\mathbf{p}$ & \\
\hline Between Groups & 3035.275 & 3 & 1011.758 & 7.825 & .000 & $\mathrm{p}<.05$ \\
\hline Within Group & 55858.585 & 432 & 129.302 & & & $\begin{array}{l}\text { significant } \\
\text { difference }\end{array}$ \\
\hline Total & 58893.860 & 435 & & & & $1-4$ \\
\hline
\end{tabular}

1: Illiterate $(\bar{X}=87,00) ; 4$ : Bachelor's Degree $(\bar{X}=86,47)$

As can be seen in table $10, \mathrm{f}$ value and $\mathrm{p}$ value as regards whether life satisfaction scale scores of adolescents change according to the education status of father were calculated 
as 3,288 and 0,021, respectively. There is statistically significant difference between scores of life satisfaction scale and education status of fathers of participants existed $(p=0,000 ; p<, 05)$. As a result of the TUKEY test which was performed in order to find between which groups this difference existed, it is seen that life satisfaction of 1: Illiterate people $(\overline{\mathrm{X}}=87,00)$ is higher compared to 4: Bachelor's Degree holders $(\bar{X}=86,47)$. Life satisfaction level of adolescents whose fathers are illiterate turned out to be higher when compared to that of adolescents with university graduate fathers. This finding which emerged according to the data obtained as a result of the analyses revealed that life expectation levels change according to the education status of father. This can be caused by the fact that targets of fathers who are university graduates are higher when compared to the targets determined by illiterate fathers. For this reason, an adolescent will find it difficult to reach the targets chosen by the father and that will decrease his/her life satisfaction. A literature review reveals that "life satisfaction of adolescents is positively affected depending on the education level of the father" (Aydoğan, 2010; Gökçakan \& Nadir, 2001; Zincirkıran, 2008). Contrary to this finding, Ünal and Şahin, in their study in 2013, concluded that education status of the father did not create a significant difference on the life satisfaction of the adolescents.

Table 11. Distribution of Life Satisfaction Levels According to the Mother's Working Status

\begin{tabular}{lllllllll}
\hline & $\mathbf{N}$ & $\bar{X}$ & $\mathbf{S}$ & $\mathbf{t}$ & $\mathbf{f}$ & $\mathbf{p}$ & \\
\hline Working & 244 & 88.55 & 11.56 & & & & $\mathrm{p}>.05$ \\
& & & & & & & \\
& & & & .363 & .434 & .463 & $\begin{array}{l}\text { no significant } \\
\text { difference }\end{array}$ \\
Non-Working & 190 & 89.38 & 12.79 & & & & \\
\hline
\end{tabular}

As can be seen in table 11, life satisfaction average scores of participants with working mothers and non-working mothers were calculated as 88,55 and 89,38, respectively. According to analysis results, no statistically significant difference was found between working status of participants and life satisfaction scale scores $(p=, 463 ; p>, 05)$. This finding which occurred according to the data obtained as a result of analysis revealed that life satisfaction level of adolescents did not change depending on the working status of mother.

Table 12. Distribution of Life Satisfaction Levels According to the Father's Working Status

$\begin{array}{lllllll}\mathbf{N} & \overline{\mathrm{X}} & \text { SS } & \mathbf{t} & \mathbf{f} & \mathbf{p}\end{array}$


no significant

As can be seen in table 12, life satisfaction average scores of participants with working fathers and non-working fathers were calculated as 89,01 and 87,00, respectively. According to analysis results, no statistically significant difference was found between working status of participants and life satisfaction scale scores $(p=, 457 ; p>, 05)$. This finding which occurred according to the data obtained as a result of analysis revealed that life satisfaction level of adolescents did not change depending on the working status of father.

\section{Conclusion and Recommendation}

In this research, an effort was paid to determine the life satisfaction of adolescents living in Northern Cyprus. The study was conducted with scanning pattern which is a quantitative method and the sample consisted of $9^{\text {th }}$ to $12^{\text {th }}$ grade students at secondary school in Kyrenia district. Conducted analyses produced the following data:

1. Distribution of life satisfaction levels of adolescents was examined parallel to the sub-dimensions of the scale. Friend satisfaction of participants was found to be the highest compared to school, environment and self-satisfaction levels. The lowest average belongs to self satisfaction sub-dimension.

2. The differentiation of life satisfaction levels of adolescents according to demographic variables was examined. The obtained results are described as follows.

- According to analyses results, it was found out that there wasn't any statistically significant difference between life satisfaction levels of adolescents based on gender.

- According to analyses results, it was found out that there wasn't any statistically significant difference between life satisfaction levels of adolescents based on age.

- According to analyses results, it was found out that there was statistically significant difference between life satisfaction levels of adolescents based on school types. As a result of the TUKEY test which was conducted to find between which groups this difference existed, it was determined that adolescents at state schools have lower life satisfaction compared to adolescents at private schools.

- According to analyses results, statistically significant difference was found in life satisfaction levels of adolescents according to their grades. As a result of the TUKEY test 
which was conducted to find between which groups this difference existed, it was determined that adolescents at $9^{\text {th }}$ grade had higher life satisfaction compared to adolescents at $12^{\text {th }}$ grade.

- According to analyses results, it was found out that there wasn't any statistically significant difference between life satisfaction levels of adolescents based on number of siblings.

- According to analyses results, it was found out that there wasn't any statistically significant difference between life satisfaction levels of adolescents based on their rank of birth.

- According to analyses results, statistically significant difference was found in life satisfaction levels of adolescents according to the education status of their mother. As a result of the TUKEY test which was conducted to find between which groups this difference existed, it was determined that adolescents whose mothers are illiterate had higher life satisfaction compared to those with university graduate mothers.

- According to analyses results, statistically significant difference was found in life satisfaction levels of adolescents according to the education status of their father. As a result of the TUKEY test which was conducted to find between which groups this difference existed, it was determined that adolescents whose fathers are illiterate had higher life satisfaction compared to those with university graduate fathers.

- According to analyses results, it was found out that there wasn't any statistically significant difference between life satisfaction levels of adolescents based on the working status of their mother.

- According to analyses results, it was found out that there wasn't any statistically significant difference between life satisfaction levels of adolescents based on the working status of their father.

Based on the results obtained in the study, some recommendations are made for correcting the detected deficiencies and directing new research. The recommendations are listed below.

Developmental support offered to students at private schools must also be offered by psychological counsellors at state schools. Number of psychological counsellors per pupil must be increased as the class populations are higher.

Psychological tests must be applied regularly for adolescents who are preparing for university entrance examinations. Psychological support must be given to adolescents at low level which will cover their family, environment, teachers and friends.

Northern Cyprus is a society which went through warfare in the near past. The parents of adolescents are negatively affected by this war. In order to understand whether this 
situation has an effect on child raising and, therefore, life satisfaction of adolescents, a casualcomparative research can be conducted between adolescents living in other countries and Northern Cyprus.

In this study, life satisfaction of adolescents was examined. In order to be able to generalize the results of the research being conducted, it is suggested that a similar research should be carried out with adolescents living in different regions and in different ethnic groups.

There are several factors which affect life satisfaction, social support and selfconfidence. People who want to perform research in this area can study using several variables care for the self, anxiety status and subjective well-being based on a relational pattern.

\section{Kaynakça / References}

Aydoğan, S. (2010). İlköğretim ikinci kademe öğrencilerinin umut ve benlik saygisı düzeylerinin bazı değişkenler açısından incelenmesi [Investigation of elementary school second grade students' hope and self-esteem levels according to some variables]. Yüksek Lisans Tezi, Selçuk Üniversitesi, Konya.

Başer, Ş. G. (2009). Lise öğrencilerinin bağlanma stilleri ve yaşam doyumlarının incelenmesi [Investigation of the relationship between attachment styles and life satisfaction of high school students]. Yüksek Lisans Tezi, Gazi Üniversitesi, Ankara.

Baştemur, Y. (2006). İş tatmini ile yaşam tatmini arasındaki ilişkiler: Kayseri Emniyet Müdürlüğ̈̈nde bir araştırma [The relationship between job satisfaction and life satisfaction]. Yüksek Lisans Tezi, Erciyes Üniversitesi, Kayseri.

Bülbül, H. S. (2004). Ergen etiği. Sürekli Tıp Eğitimi Dergisi, 13, 206-10.

Büyüköztürk, Ş.; Çokluk Bökeoğlu, Ö. \& Köklü, N. (2015). Sosyal bilimler için istatistik. Ankara: Pegem.

Cenkseven, F. (2004). Üniversite ögrencilerinde öznel ve psikolojik iyi olmanın yordayıcilarının incelenmesi [Examining the predictors of subjective and psychological wellbeing of university students]. Doktora Tezi, Çukurova Üniversitesi, Adana.

Cenkseven, F. \& Akbaş, T. (2007). Üniversite öğrencilerinde öznel ve psikolojik iyi olmanın yordayıcılarının incelenmesi [Determining the rate of university students' subjective and psychological well-being]. Türk Psikolojik Danışma ve Rehberlik Dergisi, 3(27), 43-65.

Collard, D. (2006). Research on well-being: some advice from Jeremy Bentham. Philosophyof the social sciences. 36(3), 330-354. 
Çiftci, S. (2015). Ergenlik dönemindeki ögrrencilerin asilik davranışları ile siber zorba ve siber mağdur olma düzeyleri arasındaki ilişkinin incelenmesi [The investigation of relationship between adolescent rebellious and cyber bullying and cyber victimization in adolescents]. Yüksek Lisans Tezi, Fatih Üniversitesi, İstanbul.

Çivitci. A. (2007). Çok boyutlu öğrenci yaşam doyumu ölçeğinin Türkçeye uyarlanması: Geçerlik ve güvenirlik çalışmaları [Adaptation of multidimensional student life satisfaction scale to Turkish: Validity and reliability studies]. Eğitim Araştırmaları Dergisi, 26:51-60.

Çivitci, A. (2009). İlköğretim öğrencilerinde yaşam doyumu: Bazı kişisel ve ailesel özelliklerin rolü [Life satisfaction in elementary school students: The role of some personal and familial characteristics]. Uludağ Üniversitesi Ĕ̌itim Fakültesi Dergisi, 22(1).

Demirel, S. \& Canat, S. (2004). Ankara'daki beş eğitim kurumunda kendini yaralama davranışı üzerine bir çalışma [A study on self-injury behavior in five educational institutions in Ankara]. Kriz Dergisi, 12(3), 1-9.

Diener, R.; Diener, E. \& Tamir, M. (2004). The psychology of subjective wellbein. Doedalus. 133(2), 18-25.

Doğan, T. (2006). Üniversite ögrrencilerinin sosyal zeka düzeylerinin depresyon ve bazı değişkenlerle ilişkisinin incelenmesi [The investigation of relationship between social intelligence, depression and some variables at universtiy students]. Yayınlanmamış Yüksek Lisans Tezi, Sakarya Üniversitesi Sosyal Bilimler Enstitüsü, Sakarya.

Flashman, J. (2012). Academic achievement and its impact on friend dynamics. Sociology of education. 85(1), 61-80.

Gong, Y. \& Fan, J. (2006). Longitudinal examination of the role of goal orientation in crosscultural adjustment. Journal of Applied Psychology, 91(1), 176- 184

Gökçakan, Z. \& Nadir, B. (2001). Ergende problem çözme becerisini yordayıcı bir değişken olarak benlik imgesi [Self-image as a predictor of problem-solving ability in adolescence]. VI. Ulusal Psikolojik Danışma ve Rehberlik Kongresi, Bildiri Özetleri Kitabı, Türk Psikolojik Danışma ve Rehberlik Derneği, Yayın, (8), 5-7.

Gülcan, A. \& Bal, P. (2014). Genç yetişkinlerde iyimserliğin mutluluk ve yaşam doyumu üzerindeki etkisinin incelenmesi [Investigating the effect of optimism on happiness and life satisfaction of young adults]. Asian Journal of Instruction, 2(1).

Hilooğlu, S. \& Cenkseven-Önder, F. (2010). İlköğretim ikinci kademe öğrencilerinde zorbalığı yordamada sosyal beceri ve yaşam doyumunun rolü [The role of social skill and life satisfaction in the bullying process in primary school second degree students]. Illkögretim Online, 9(3), 1159-1173.

Karasar, N. (2012). Bilimsel araştırma yöntemleri. Ankara: Nobel Yayın Dağıtım. 
Kaya, A. \& Saçkes, M. (2016). Benlik saygısı geliştirme programının ilköğretim 8. sınıf öğrencilerinin benlik saygısı düzeylerine etkisi [The effect of the self-esteem development program on the self-esteem levels of primary school 8th graders]. Türk Psikolojik Danışma ve Rehberlik Dergisi, 3(21).

Kırt1l, S. (2009). İlköğretim ikinci kademe ögrencilerinin duygusal zeka düzeyleri ile yaşam doyumu düzeylerinin incelenmesi [Examination of emotional intelligence levels and life satisfaction levels of primary school second level students]. Doktora Tezi, Dokuz Eylül Üniversitesi, İzmir.

Kiraz A. \& Özyurtlu R. (2014). Determination of the burnout levels and perfectionism levels in science teachers. Cypriot Journal of Educational Sciences, 9(2), 117-128.

Kulaksızoğlu, A. (2009). Ergenlik psikolojisi (11. Bask1). İstanbul: Remzi Kitabevi

Küey, A. G. (2008). Yeme bozuklukları [Eating disorders]. Adolesan Sağlığı II, Sempozyum Dizisi, 63:81-83.

Lubin, B. \& Van Whitlock, R. (2004). Psychometric properties of the brief life satisfaction scales. Journal of clinical psychology, 60(1), 11-27.

Mahon, N. E.; Yarcheski, A. \& Yarcheski T. J. (2005). Happiness as related to gender and health in early adolescents. Clinical nursing research. 14, 2, 175-190.

Özer, M. \& Karabulut, Ö. (2003). Yaşlılarda yaşam doyumu [Life satisfaction in old people]. Turkish Journal of Geriatrics, 6(2), 72-74.

Parman, T. (2008). Ergenliğin yüzleri. İstanbul: Bağlam Yayıncılık.

Selçukoğlu, Z. (2001). Araştırma görevlilerinde tükenmişlik düzeyi ile yalnızlık düzeyi ve yaşam doyumu arasındaki ilişkinin bazı değişkenler açısından değerlendirilmesi [Assessment of the relationship between burnout level, loneliness level and life satisfaction in research staff in terms of some variables]. Selçuk Üniversitesi, Konya.

Şener, Ş. (2008). Beden eğitimi ögretmenlerinin tükenmişlik ve yaşam doyumu düzeyleri [Burnout and life satisfaction levels of physical education teachers]. Yüksek Lisans Tezi, Mersin Üniversitesi, Mersin.

Tezel, A.; Dzkanz, H. \& Parlak, A. (2012). Bir okul Sağlığı Hemşireliği Uygulama Programı: Erzurum İl Merkezinde Bir İlköğretim Okul Öğrencilerinin Depresyon Düzeyleri [A School Health Nursing Practice Program: The Depression Levels of a Primary School Student in Erzurum City Center]. Bozok Tip Dergisi, 2:23-28.

Ünal, A. Ö. \& Şahin, M. (2013). Lise öğrencilerinin yaşam doyumlarının bazı değişkenlere göre yordanması [A prediction of life satisfaction of high school students according to some variables]. Cumhuriyet International Journal of Education, 2(3).

Zincirkıran, Z. (2008). Okul öncesi ĕgitim kurumlarına devam eden altı yaş grubu çocuklarının benlik kavramının bazı değişkenlere göre incelenmesi [Examination of the self concept of the children of the age group of six years who continue to pre-school education institutions according to some variables]. Yüksek Lisans Tezi, Maltepe Üniversitesi, İstanbul. 